\title{
Turkish Version of Bruininks-Oseretsky Test of Motor Proficiency 2 Brief Form: Its Validity and Reliability in Children with Specific Learning Disability
}

\author{
Bruininks-Oseretsky Motor Yeterlik Testi 2 Kısa Formunun Türkçe Uyarlaması \\ ve Özgül Öğrenme Güçlüğü Olan Çocuklarda Geçerlilik ve Güvenilirliği
}

\author{
(iD Barkın KÖSE1, id Sedef ŞAHIN11, id Erdem KARABULUT22, id Hülya KAYIHAN3 \\ 'Hacettepe University Faculty of Health Sciences, Division of Occupational Therapy, Ankara, Turkey \\ ${ }^{2}$ Hacettepe University Faculty of Medicine, Department of Biostatistics, Ankara, Turkey \\ ${ }^{3}$ Biruni University Faculty of Health Sciences, Division of Occupational Therapy, İstanbul, Turkey
}

\section{ABSTRACT}

Objective: Specialists often assess the motor proficiency of children presented with suspected developmental delays. It is essential that the tools used to assess children have highly powerful measurement properties including psychometric properties. The aim of our study, analyze the reliability and construct validity of the Turkish version of the Bruininks Oseretsky Test of Motor Proficiency 2-Brief Form (BOT2-BF) in children with a specific learning disability (SLD).

Methods: Participants, which aged between 6 and 14, were included 137 children with SLD and 50 children without any diagnosis. The Turkish version of the BOT2-BF was administered by the researcher in one session to children with SLD twice with a seven days interval. In addition, BOT2-BF was re-apply to 25 children with SLD, which were randomly selected, after 10 days.

Results: The validity results of BOT2-BF were found to be significantly better in all subtests in the control group than in the study group, having higher performance levels $(\mathrm{p}<0.05)$. The BOT2-BF demonstrated high test-retest reliability $($ ICC $>0.8$ ) (except Fine Motor Precision ( $\mathrm{ICC}=0.57$ ) and Manual Dexterity Subtest (ICC=0.74) and good internal consistency (Cronbach's alpha $=0.78)$ for all domains. The inter-rater reliability results were found to be perfectly reliable (ICC $>0.9$ ).
ÖZ

Amaç: Uzmanlar genellikle gelişimsel gecikmelerinden şüphelendikleri çocukların motor yeterliliklerini değerlendirirler. Çocukları değerlendirmek için kullanılan testlerin psikometrik özellikler de dahil olmak üzere kanıt değerliliği açısından güçlü ölçüm özelliklerine sahip olmaları önemlidir. Çalışmamızın amac1, özgül öğrenme güçlüğü (ÖÖG) olan çocuklarda Bruininks Oseretsky Motor Yeterlilik Testi 2-Kısa Formunun (BOT2-KF) Türkçe versiyonunun güvenilirliğini ve yapı geçerliliğini analiz etmektir.

Yöntemler: Çalışmamıza 6-14 yaş arasındaki, 137 ÖÖG tanısı almış ve 50 herhangi bir tanı almamış (sağlıklı), çocuk dahil edildi. BOT2-KF'nin Türkçe versiyonu, ÖÖG'li çocuklara bir araştırmacı tarafından tek oturumda mola verilmeden, yedi gün arayla iki kez uygulandı. Ek olarak, BOT2-KF 10 gün sonra rastgele seçilen ÖÖG’li 25 çocuğa tekrar uygulandı.

Bulgular: BOT2-KF'nin geçerlilik sonuçlarının, kontrol grubundaki tüm alt testlerde çalışma grubuna göre daha yüksek olduğu ve daha yüksek performans düzeylerine sahip olduğu bulundu $(\mathrm{p}<0,05)$. BOT2-KF, tüm etki alanları için yüksek testtekrar )ince motor hassasiyeti (ICC $=0,57)$ ve el becerisi alt testi (ICC $=0,74)$ hariç test güvenilirliği (ICC $>0,8)$ ve iyi düzeyde iç tutarlılık (Cronbach's alpha=0,78) göstermiştir. Değerlendiriciler
Address for Correspondence: Barkın KÖSE, Hacettepe University Faculty of Health Sciences, Division of Occupational Therapy, Ankara, Turkey

E-mail: barkinkose@gmail.com ORCID ID: orcid.org/0000-0002-2840-3309

Cite this article as: Köse B, Şahin S, Karabulut E, Kayıhan H. Turkish Version of Bruininks-Oseretsky Test of Motor Proficiency 2 Brief Form: Its Validity and Reliability in Children with Specific Learning Disability. . Bezmialem Science 2021;9(2):198-204.

${ }^{\circledR}$ Copyright 2021 by the Bezmiâlem Vakıf University

Bezmiâlem Science published by Galenos Publishing House.
Received: 17.02 .2020

Accepted: 15.01.2021 
Conclusion: The Turkish version of BOT2-BF was found to be a valid and reliable assessment to evaluate motor proficiency in children with SLD.

Keywords: Specific learning disability, motor proficiency, validity, reliability arası güvenilirlik sonuçlarının mükemmel derecede güvenilir olduğu bulunmuştur (ICC $>0,9$ ).

Sonuç: BOT2-KF'nin Türkçe versiyonunun SLD'li çocuklarda motor yeterliliği değerlendirmek için geçerli ve güvenilir bir değerlendirme olduğu bulunmuştur.

Anahtar Sözcükler: Özgül öğrenme güçlüğü, motor yeterlilik, geçerlilik, güvenilirlik

\section{Introduction}

Specific Learning Disorder (SLD) is a developmental disorder with a neurological origin seen in individuals who actually have normal or above normal intelligence (IQ $>85$ ) but no primary psychological disorder, obvious brain damage, or sensory disability, experiencing certain difficulties in the acquisition. Children with SLD encounter many problems in activities, such as listening, speaking, reading, writing, reasoning, math skills, self-governance, understanding social events, and establishing social communication (1-5). Son and Meisels (6) grouped under two main headings and revealed that children with SLD had problems in self-care and academic activities performance.

Children with SLD was observed to face difficulties in performing activities such as shoe lacing, tooth brushing, dressing, buttoning up of clothes, and falling down while climbing up or down the stairs especially in daily living $(6,7)$. In academic life, children have problems in holding a pencil, writing legibly, doing mathematical operations, and simultaneously writing down a text dictated by the teacher $(8,9)$. Given these problems encountered by children with SLD in activities of daily life, weak muscle strength, weakness in fine and gross motor abilities, insufficiency of balance-coordination, visual perception problems, and failure to perform sequential skills come to the forefront as problems of motor proficiency (10-12).

Motor proficiency was defined as the level of realization of motor abilities such as balance, coordination, and orientation using a combination with sensory and perceptual skills (13). BruininksOseretsky Motor Proficiency Test 2 (BOT2), BruininksOseretsky Motor Proficiency Test 2 Brief form (BOT2-BF), Fundamental Movement Pattern Assessment Instrument, and Developmental Sequence of Fundamental Motor Skills Inventory and Gross Motor Development Test are used commonly to assess motor proficiency levels in the children (14-18). Considering the features of these tests used in this field, BOT2-BF comes to the fore for its features like short duration, understandable and easyto-conduct, and providing holistic evaluation features.

Bruininks-Oseretsky Motor Proficiency Test (BOMPT) was developed in 1972 in order to measure the motor abilities of children aged between 4.5 and 14.5 years (15). BOMPT was updated in 2005 and became BOT2. Thus, BOT2 is applicable to children and youth 4-21 years of age. Administration of the BOT2 contains eight sub-test with 42 items and takes approximately 45-60 min (15). The validity and reliability of the BOT2 was determined by Balli with a study conducted on a group of healthy children aged 5 years in Turkey in 2012 (19).

BOMPT Short Form, which is the old version of BOT2$\mathrm{BF}$, contains eight sub-test and 14 items. It takes 20-25 min. BOMPT Short Form was updated in 2010 and became BOT $2-\mathrm{BF}$, reducing the total number of items from 14 to 12 . This version takes $15-20 \mathrm{~min}$ (13). It is important to show version in different languages due to BOT2-BF could be completed in a short time practically to assess motor abilities in children. Therefore, this study aimed to assess the reliability and validity of the Turkish version of the BOT2-BF among children with SLD.

\section{Methods}

Our study was evaluated by University Non-invasive Clinical Research Ethics Committee and found to be ethically appropriate on 21.11.2017 with the decision GO17/892-26. The permission required for the application of the Turkish version of BOT2-BF was obtained at the beginning of the study from the licensee. All participants and their parents agreed to participate in the study and were informed about the study and their consent was obtained.

\section{Participants}

The study was conducted at the pediatric clinic of the department of Occupational Therapy at the University. Inclusion criteria for the study group were the following: (1) diagnosed with SLD according to Diagnostic and Statistical Manual of Mental Disorders V criteria, (2) between 4-21 years of age, (3) volunteer to participate in the study, (4) absence of other diagnosis (e.g.,., attention deficit hyper-activity, autism, etc.), and (5) not professionally involved in any sportive activity (gym, volleyball, basketball, etc.). Inclusion criteria for the control group were as follows: (1) between 4-21 years of age, (2) voluntary participation to the study, (3) not professionally involved in any sportive activity (gym, volleyball, basketball, etc.), and (4) not born as preterm (20).

In the calculation of minimum sample size, which is 120 children with SLD and 40 children without any diagnosis, the model developed by Tabachnik and Fidell was used (21-23). During the study period, children who applied at the occupational therapy department for treatment were screened as potential participants. In this process, who could not be included or does not continue the study due to various reasons was noted. As a result, 137 healthy children were included in our study as the study group 
and 50 children without any diagnosis as the control group (Figure1-Flow Chart).

\section{Measures}

\section{Demographic Information Form}

A demographic information form was completed by participants. Information included participants' age, gender, class, and dominant hand information.

\section{Bruininks-Oseretsky Test of Motor Proficiency-Brief Form (BOT 2-BF)}

BOT2-BF consists of eight sub-tests with 12 items. Test duration takes nearly 15-20 min. Sub-tests and items of BOT2-BF are as follows: (1) Fine Motor Accuracy: Completing the inside of a star and drawing a line along a path; (2) Fine Motor Integration: Copying nested circles and copying a diamond shape; (3) Manual Dexterity: Tying blocks on to a string; (4) Bilateral Coordination: Touching the tip of the nose with the index finger (eyes closed) and drawing a square with the thumb and index finger; (5) Balance: Walking forward heel-to-toe on a line (6) Speed and Agility: Jumping on one foot; (7) Coordination of Upper Extremities: Catching a thrown ball (with one hand) and

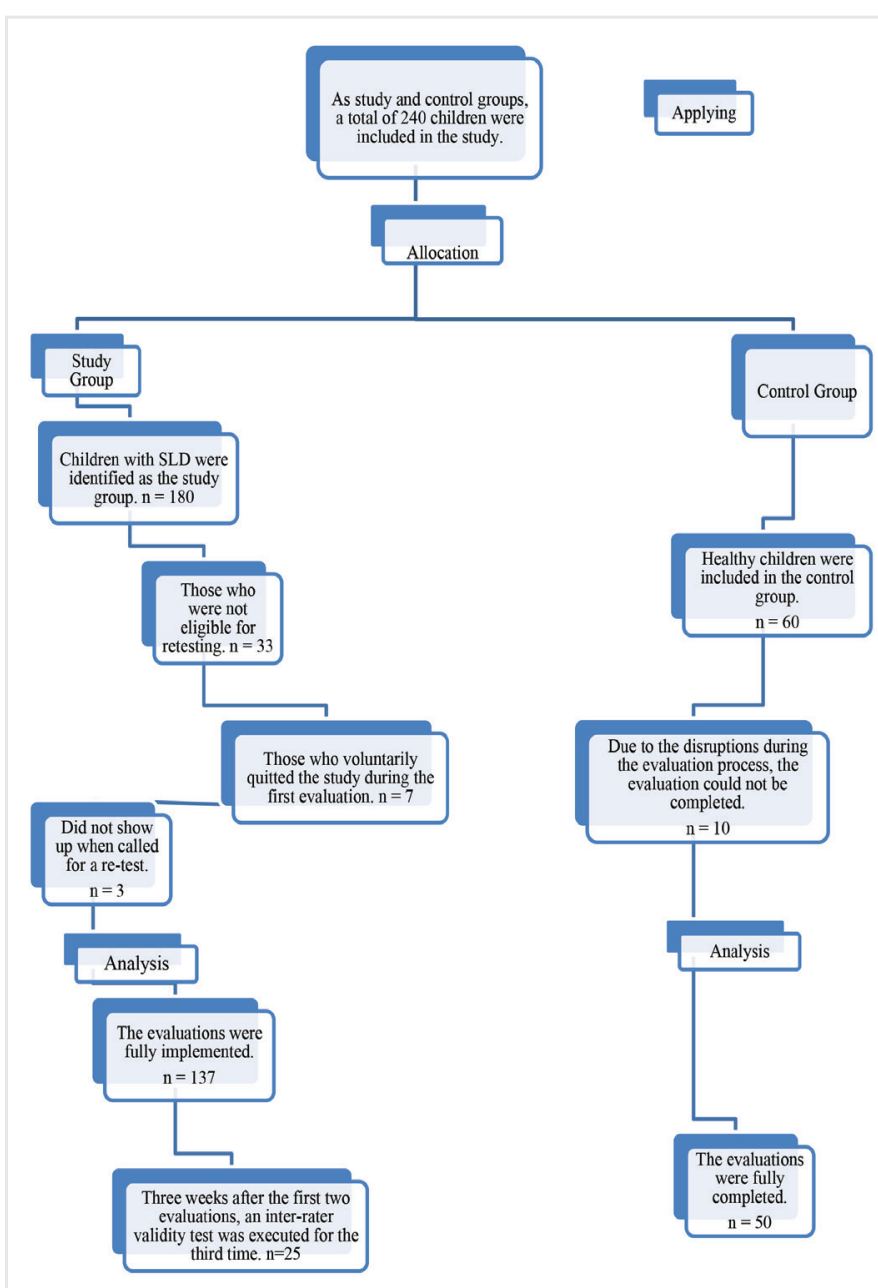

Figure 1. Flow chart dribbling; and (8) Endurance: Full push-ups and push-ups on knees (13).

Item point scores for each task are converted to processed points using the Likert scale in each task. The Likert score values for each task are different. The conversion of the item point scores to the processed score is made by finding the processed score on the Likert scale that corresponds to the raw score taken from the best performance. In all items, the second trial is not performed if the child has received a full score on the first attempt. The internal consistency of the test was found to be sufficient (Cronbach's $\alpha=0.87$ ) (13).

\section{Procedures}

Demographic data of participants were recorded. BOT2-BF was applied to the study and control groups to determine the motor capabilities of children. For the determination of test-retest reliability, BOT2-BF was re-administered to the study group a week after the initial evaluations. All evaluations were carried out by a single therapist (BK) during a single face-to-face session with children. Following the second evaluation of the study group, 25 children were randomly selected from the study group to determine the inter-rater reliability, and a third evaluation was carried out on them by another therapist (HK) 10 days after the first two evaluations (24).

\section{Translation and Cross-Cultural Adaptation}

The BOT2-BF was adapted from English version into Turkish in accordance with its standard methodology recommended by Beaton et al. (25). The adaptation was performed by two independent native speaking Turkish translators with fluent knowledge in English. The final Turkish version of the adaptation was later translated from Turkish to English by two English native speakers who can speak Turkish fluently to check compatibility. A committee with expertise in this field reviewed the translations and procedure. The comparison of the translation to the original version of the test revealed no inconsistency.

\section{Data Analysis}

International Business Machines Statistical Package for the Social Sciences Statistics for Windows version 23.00 was used for statistical analysis of data. The Kolmogorov-Smirnov Test was used to determine whether the data showed normal distribution. Categorical variables were expressed as numbers and percentages, whereas quantitative data were expressed as mean and standard deviation (26-28).

\section{Validity Analysis}

A construct validity was used to determine the validity degree of BOT 2-BF. In our study, the construct validity of BOT2-BF was evaluated through Known-Groups validity. This analysis was performed with children who were diagnosed with SLD and children without any diagnosis. The normal distribution assumption could not be obtained, thus the scale scores were analyzed with Mann-Whitney U Test to see whether they were different in two groups, and statistical significance level was accepted to be $0.05(27,29)$. 


\section{Reliability Analysis}

In our study, internal consistency and item analysis methods were used for the analysis of the reliability of the scale, and testretest method and inter-rater reliability method were used for invariance reliability over time. Internal consistency has been indicated as Cronbach's alpha value. An alpha value $>0.70$ is indicative of a satisfactory consistency, whereas values between 0.50 and 0.70 are mean acceptable consistency (30). In our study, mixed model of intra-class correlation coefficient (ICC) was used for the inter-rater and test-retest reliability analyses of BOT2-BF. Intervals used for the interpretation of ICC values include the following: values $<0.5$ means poor reliability; 0.50 0.74 mean moderate reliability; $0.75-0.90$ fine reliability; and $>0.90$ are defined as excellent degree of reliability (30).

\section{Results}

\section{Descriptive Statistics}

The average age of children included in the study are as follows: children in the study group $(\mathrm{n}=137)$ was $10.07 \pm 2.22$ years [minimum (min) 6, maximum (max) 14 years] and in the control group ( $\mathrm{n}=50)$ was $9.94 \pm 2.29$ years (min: 7 , max: 15 years). Both groups had resembled each other $(\mathrm{Z}=-1.98 ; \mathrm{p}=0.4)$.

\section{Validity}

\section{Construct Validity}

With the exception of Fine Motor Precision and Strength Tests, validity results of BOT2-BF were found to be significantly better in all other sub-tests in the control group than in the study group, having higher performance levels $(\mathrm{p}<0.05)$. Sub-results of the construct validity are shown in Table 1 .

\section{Reliability}

\section{Internal Consistency Reliability}

As a result of statistical analysis, the internal consistency of BOT2-BF was found to be statistically sufficient (Cronbach's $\alpha=0.78$ ). Results of the internal consistency and item analysis of the test are shown in Table 2.

\section{Test-Retest Reliability}

Fine Motor Precision sub-test $(\mathrm{ICC}=0.57)$ and Manual Dexterity sub-test $(\mathrm{ICC}=0.74)$ of $\mathrm{BOT} 2-\mathrm{BF}$ were found to be moderately

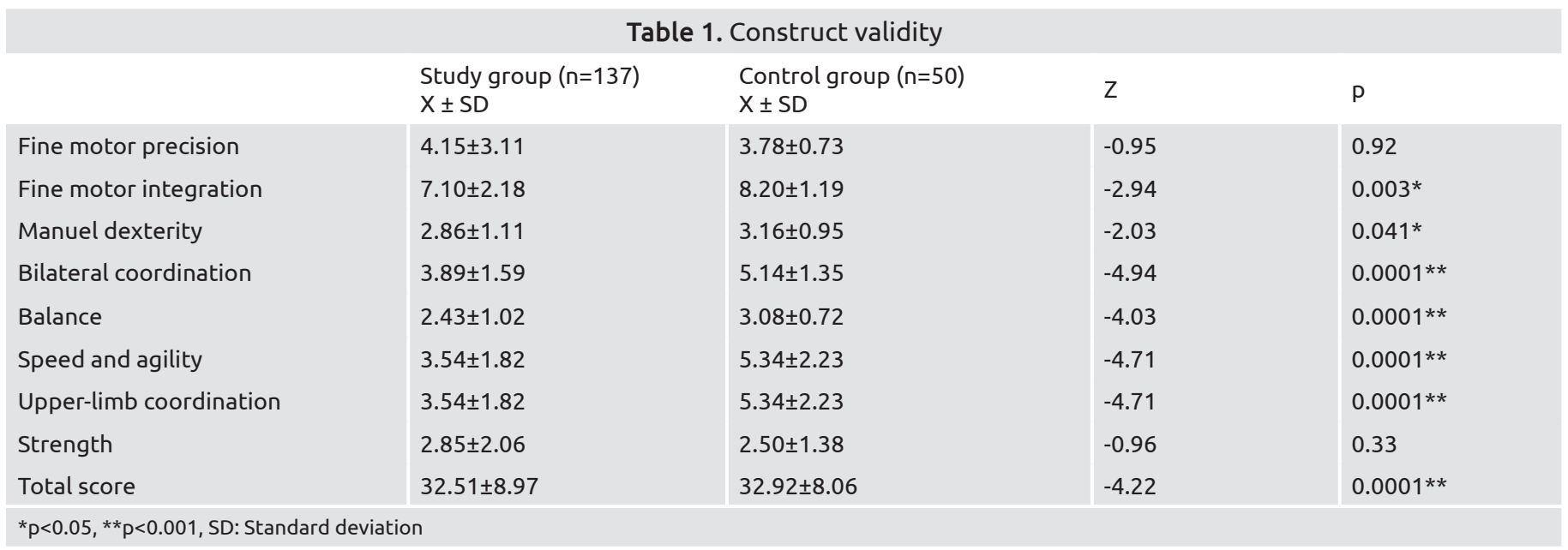

Table 2. Internal consistency reliability

\begin{tabular}{|c|c|c|c|}
\hline Item & $\begin{array}{l}\text { Mean-standard deviation }(n=137) \\
(X \pm S D)\end{array}$ & $\begin{array}{l}\text { Corrected item-total correlation } \\
(\ulcorner)\end{array}$ & a if item deleted \\
\hline Item 1 & $2.70 \pm 0.57$ & 0.44 & 0.78 \\
\hline Item 3 & $3.94 \pm 1.10$ & 0.43 & 0.77 \\
\hline Item 4 & $3.21 \pm 1.35$ & 0.49 & 0.76 \\
\hline Item 5 & $2.80 \pm 0.93$ & 0.53 & 0.77 \\
\hline Item 7 & $1.23 \pm 1.08$ & 0.12 & 0.79 \\
\hline Item 8 & $2.38 \pm 1.02$ & 0.50 & 0.77 \\
\hline Item 9 & $3.57 \pm 1.80$ & 0.62 & 0.75 \\
\hline Item 10 & $2.05 \pm 1.65$ & 0.51 & 0.76 \\
\hline Item 11 & $4.02 \pm 1.94$ & 0.59 & 0.75 \\
\hline
\end{tabular}


reliable. Other sub-tests except those two were found to be between fine and excellent reliable. The invariance reliability sub-results of BOT2-BF over time are presented in Table 3.

\section{Inter-Rater Reliability}

All sub-tests of BOT2-BF were found to be perfectly reliable. The inter-rater reliability subscales of BOT2-BF are shown in Table 4.

\section{Discussion}

This study describes the translation and psychometric testing in terms of validity (construct) and reliability (Internal Consistency, Test-Retest, and Inter-Rater) of the Turkish version of the BOT2$\mathrm{BF}$ in children with SLD. Analyzing the psychometric properties of tests in the literature, study examples investigating the features of BOT2 and BOT2-BF were found to be limited. An acceptable reliability and validity were observed only in the study carried out by Lucas et al. (31) using BOT2-BF on children who live in rural areas. As for BOT 2, psychometric features and normative data have been investigated in studies generally conducted on healthy children and children diagnosed with mental retardation (19,31-36). Therefore, studies dwelling into the validity and reliability features of BOT2 and BOT2-BF tests that evaluate motor abilities were also studied (19,34-36).
Factor analysis was used for construct validity in example studies that already exist in literature. However, in our study, construct validity was measured by means of the Known-Groups Validity. This is because the test is not suitable for factor analysis due to the number and distribution of items (26). As our results have satisfactory contract validity between children with SLD and controls matched for age and gender.

For all sub-tests of the Turkish version, the internal consistency of the BOT2-BF was found to be acceptable (coefficient alpha values were $\geq 0.7)$. The degree of internal consistency observed in the present study $(\alpha=0.78)$ was lower than that of the original validation study of the BOT2-BF $(\alpha=0.85)$ (13). Other version studies using BOT2-BFwere not found other than the original study in literature. In this respect, our study is the first version study using BOT2-BF and it is also the first study to show its usability in children with SLD.

The original version examined the reliability of BOT 2-BF via test and retest methods. As for the study results, the invariance of items in time varied from medium to good validity (13). In addition, Wuang and $\mathrm{Su}(36)$ used the test and retest analysis in the BOT2 version study and found the test to be reliable enough. In our study, the invariance of BOT2-BF in time was examined via test and retest methods similar to the examples in literature.

Table 3. Test-retest reliability

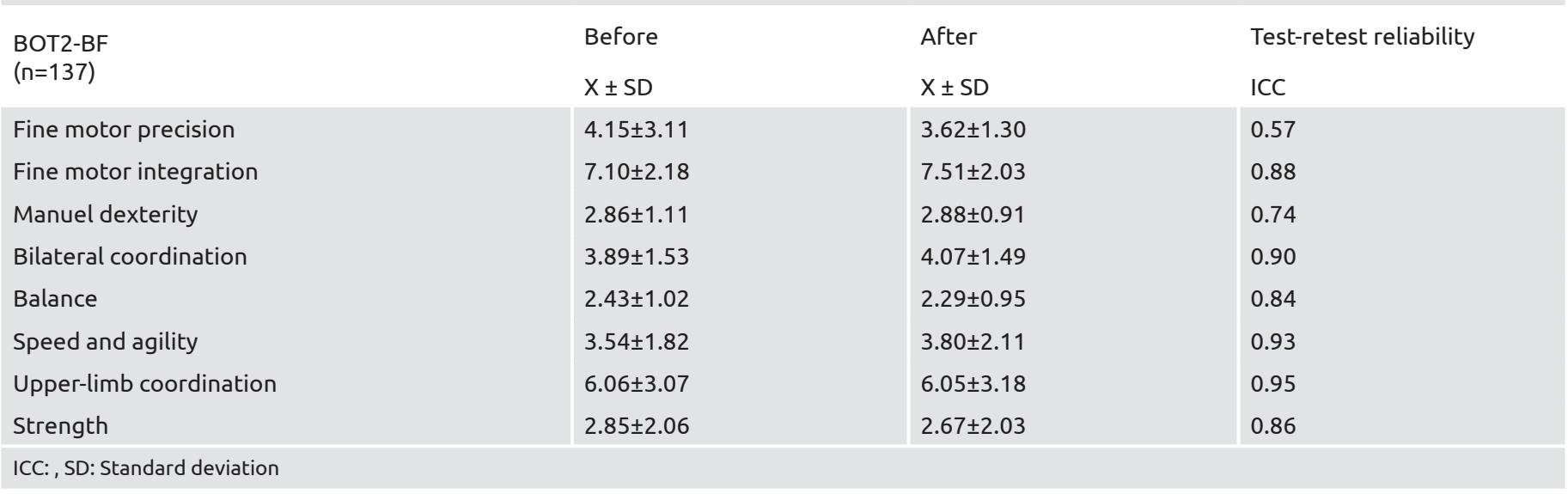

Table 4. Inter-rater reliability

\begin{tabular}{|c|c|c|c|}
\hline & $\begin{array}{l}\text { Therapist } 1 \\
(n=25) \\
X \pm S D\end{array}$ & $\begin{array}{l}\text { Therapist } 2 \\
(n=25) \\
X \pm S D\end{array}$ & $\begin{array}{l}\text { Inter-rater } \\
\text { ICC }\end{array}$ \\
\hline Fine motor precision & $4.15 \pm 3.11$ & $4.80 \pm 4.74$ & 0.99 \\
\hline Fine motor integration & $7.10 \pm 2.18$ & $7.20 \pm 2.46$ & 0.99 \\
\hline Manuel dexterity & $2.86 \pm 1.11$ & $2.96 \pm 1.39$ & 1.00 \\
\hline Bilateral coordination & $3.89 \pm 1.59$ & $3.88 \pm 1.48$ & 1.00 \\
\hline Speed and agility & $3.54 \pm 1.82$ & $3.84 \pm 1.86$ & 1.00 \\
\hline Upper-limb coordination & $6.06 \pm 3.07$ & $6.40 \pm 2.51$ & 1.00 \\
\hline Strength & $2.85 \pm 2.06$ & $2.24 \pm 1.92$ & 1.00 \\
\hline Total score & $32.51 \pm 8.97$ & $32.28 \pm 7.44$ & 1.00 \\
\hline
\end{tabular}


Compatible with the literature, results of the reliability of time invariance ranged from medium to excellent. This point of view, unlike the original version, results of speed and agility and upperlimb coordination sub-tests were found to be higher in our study.

In the original version, Bruininks and Bruininks (13) demonstrated an excellent inter-rater reliability of BOT2-BF. We also measured the inter-rater reliability of the BOT2-BF as an assessment tool in the Turkish version that could make a difference between practitioners. In our study results similar to the original version, the reliability level of items was found to be excellent. Considering these values, our study can be considered to have an excellent degree of reliability, in contrast with results of many examples in literature. The degree of excellence in reliability means that the Turkish version of BOT 2-BF can easily be adopted and used by many experts.

When the version studies in the literature conducted using BOMYT, BOMYT Short Form, BOT2, and BOT 2-BF are considered, sample groups in most studies can be selected from children without disabilities. Studies were conducted in only healthy children, which may be led to a significant deficiency in rehabilitation clinics for children with disability. The application of these tests in the evaluation of rehabilitation programs on disability groups are unknown $(13,15,34-37)$. Thus, we believe that our study will positively contribute both to the literature and clinical professionals, as it has included children with SLD.

\section{Study Limitations}

Due to the time limitation in our study, adequate number of participants could not be included to make a better distribution analysis according to ages, which can be regarded as a limitation of our study. Examining the methodology of other studies in the literature, it can be seen that results are introduced according to age distributions $(13,36)$. Taking into consideration the fact that distribution by age can provide positive contributions in the interpretation of evaluations that have been made by experts working in the clinical field, examining those distributions according to ages in the following studies were thought to be crucial.

\section{Conclusion}

This has been the first study to evaluate the validity and reliability of the BOT2-BF, which measures motor competence, planning, orientation, coordination, and speed in children with SLD. Considering the fact that studies conducted in this area focus largely on healthy groups, it is thought that it will contribute positively to the development of further study fields to assist both academic and clinical professionals. It is considered essential that further studies where BOT2-BF is used should be conducted to obtain validity and reliability as well as high value of evidence in clinical practices.

\section{Ethics}

Ethics Committee Approval: Our study was evaluated by University Non-invasive Clinical Research Ethics Committee and found to be ethically appropriate on 21.11.2017 with the decision GO17 /892-26.

Informed Consent: All participants and their parents agreed to participate in the study and were informed about the study and their consent was obtained.

Peer-review: Externally peer reviewed.

\section{Authorship Contributions}

Concept: B.K., H.K., Design: B.K., S.Ş., E.K., Data Collection or Processing: B.K., S.Ş., Analysis or Interpretation: E.K., Literature Search: B.K., H.K., Writing: B.K., S.Ş., E.K., H.K.

Conflict of Interest: No conflict of interest was declared by the authors.

Financial Disclosure: Expenses of our research were covered by the project number 16698 by University Scientific Research Projects Coordination Unit.

\section{References}

1. Demir B. Okulöncesi ve ilköğretim birinci sınıfa devam eden öğrencilerde özel öğrenme güçlüğünün belirlenmesi. Yayınlanmamış Yüksek Lisans Tezi, Marmara Üniversitesi, Eğitim Bilimleri Enstitüsü, İstanbul. 2005.

2. Kavale KA, Forness SR. What definitions of learning disability say and don't say: a critical analysis. J Learn Disabil 2000;33:239-56.

3. Ozkardes OG. Türkiye’de Özel Öğrenme Güçlüğüne İlişkin Yapılan Araştırmaların Betimsel Analizi. Boğaziçi Üniversitesi Eğitim Dergisi 2013;30:123-53.

4. Polat E, Adiguzel T, Akgun OE. Adaptive Web-Assisted Learning System for Students with Specific Learning Disabilities: A Needs Analysis Study. Educational Sciences: Theory and Practice 2012;12:3243-58.

5. Tercan H, Bıçakcı MY. Children with Specific Learning Disability. Recent Advances in Health Sciences. 393.

6. Son SHC, Meisels S. The relationship of young children's motor skills to later reading and math achievement. Merrill-Palmer Quarterly 2006;52:755-78.

7. Viholainen H, Ahonen T, Lyytinen P, Cantell M, Tolvanen A, Lyytinen $\mathrm{H}$. Early motor development and later language and reading skills in children at risk of familial dyslexia. Dev Med Child Neurol 2006;48:367-73.

8. McDermott RP. The acquisition of a child by a learning disability. Understanding learning: Influences and outcomes 2001:269-305.

9. Westendorp M, Hartman E, Houwen S, Smith J, Visscher C. The relationship between gross motor skills and academic achievement in children with learning disabilities. Res Dev Disabil 2011;32:2773-9.

10. Fawcett AJ, Nicolson RI, Dean P. Impaired performance of children with dyslexia on a range of cerebellar tasks. Ann Dyslexia 1996;46:259-83.

11. Fawcett AJ, Nicolson RI. Automatisation deficits in balance for dyslexic children. Percept Mot Skills 1992;75:507-29. 
12. Nicolson R, Fawcett AJ, Dean P. Dyslexia, development and the cerebellum. Trends Neurosci 2001;24:515-6.

13. Bruininks RH, Bruininks BD. Bruininks-Oseretsky test of motor proficiency, second edition, brief form. Bloomington: PsychCorp.; 2010.

14. Anlar B, Yalaz K. Denver II Gelişimsel Tarama Testi-Türk Çocuklarına Uyarlanması ve Standardizasyonu. Hacettepe Çocuk Nörolojisi Gelişimsel Tıp Araştırmaları Grubu, Ankara. 1996.

15. Bruininks RH, Bruininks BD. BOT2: Bruininks-oseretsky test of motor proficiency: AGS Publishing; 2005.

16. Gallahue D, Ozmun JC, Goodway JC. Understanding motor development: Infants, children, adolescents, adults: Mcgraw-hill; 1998.

17. King HA, Aufsesser PM. A Decision-Theoretic Examination of the Usefulness of Two Motor Performance Tests in Identifying Children for Assignment to Adapted Physical Education. 1984. p. 105.

18. Donnelly FC, Mueller SS, Gallahue DL. Developmental Physical Education for Today's Children. Human Kinetics. 2003.

19. Balli OM, Gursoy F. Bruininks-Oseretsky Motor Yeterlik Testinin Beş-Altiyaş Grubu Türk Çocuklar İçin Geçerlik Ve Güvenirlik Çalişmasi. Spor Bilimleri Dergisi 2012;23:104-18.

20. Association AP. Diagnostic and statistical manual of mental disorders Fifth Edition. American Psychiatric Pub; 2013.

21. Bayaga A. MULTINOMIAL LOGISTIC REGRESSION: USAGE AND APPLICATION IN RISK ANALYSIS. Journal of applied quantitative methods. 2010;5:288-97.

22. Tabachnick BG, Fidell LS, Ullman JB. Using multivariate statistics: Pearson Boston, MA; 2007;1-14.

23. Tabachnick BG, Fidell LS. SAS for windows workbook for Tabachnick and Fidell using multivariate statistics: Allyn and Bacon; 2001.

24. Ercan I, Kan I. Reliability and validity in the scales. Uludağ Üniversitesi Tip Fakültesi Dergisi 2004;30:211-6.

25. Beaton DE, Bombardier C, Guillemin F, Ferraz MB. Guidelines for the process of cross-cultural adaptation of self-report measures. Spine (Phila Pa 1976) 2000;25:3186-91.
26. Alpar R. Performance tests of validity and reliability. Spor Bilimlerinde Uygulamalı İstatistik 2nd ed İstanbul: Nobel Yayın Dağıtım. 2001: s. 261.

27. Alpar R. Spor, sağlık ve eğitim bilimlerinden örneklerle uygulamalı istatistik ve geçerlik-güvenirlik: Detay Yayıncılık.; 2010.

28. Lilliefors HW. On the Kolmogorov-Smirnov Test for Normality with Mean and Variance Unknown. Journal of the American Statistical Association 1967;62:399-402.

29. Finch E. Physical rehabilitation outcome measures. A guide to enhanced clinical decision making 2002;64.

30. Portney LG, Watkins MP. Foundations of Clinical Research: applications to practice: Pearson/Prentice Hall Upper Saddle River, NJ.; 2009; s. 892.

31. Lucas BR, Latimer J, Doney R, Ferreira ML, Adams R, Hawkes G, et al. The Bruininks-Oseretsky Test of Motor Proficiency-Short Form is reliable in children living in remote Australian Aboriginal communities. BMC Pediatr 2013;13:135.

32. Blank R. Bruininks-Oseretzky Test der motorischen Fähigkeiten: Handbuch; Grundlagen, Testauswertung und Interpretation: Pearson; 2014.

33. Deitz JC, Kartin D, Kopp K. Review of the Bruininks-Oseretsky Test of Motor Proficiency, Second Edition (BOT-2). Phys Occup Ther Pediatr 2007;27:87-102.

34. Hassan MM. Validity and reliability for the Bruininks-Oseretsky Test of Motor Proficiency-Short Form as applied in the United Arab Emirates culture. Percept Mot Skills 2001;92:157-66.

35. Kambas A, Aggeloussis N. Construct validity of the BruininksOseretsky Test of Motor Proficiency-short form for a sample of Greek preschool and primary school children. Percept Mot Skills 2006;102:65-72.

36. Wuang YP, Su CY. Reliability and responsiveness of the BruininksOseretsky Test of Motor Proficiency-Second Edition in children with intellectual disability. Res Dev Disabil 2009;30:847-55.

37. Bruininks VL, Bruininks RH. Motor proficiency of learning disabled and nondisabled students. Percept Mot Skills 1977;44:1131-7. 